\title{
Natural infection of Trypanosoma sp. in domestic sheep from Ecuador
}

\author{
Roberto Darwin Coello-Peralta ${ }^{*}$ (i) Nelson Catito Cabrera Solórzano ${ }^{2}$ (i) \\ María de Lourdes Salazar Mazamba ${ }^{1}$ (D) Enrique Omar Reyes Echeverria ${ }^{1}$ (i) \\ Lucía Ligia Andrade Velásquez ${ }^{1}$ (i) Betty Judith Pazmiño Gómez ${ }^{3}$ (D)
}

${ }^{1}$ Faculty of Veterinary Medicine and Zootechnics (FMVZ), University of Guayaquil (UG), 090112, Guayaquil, Ecuador. E-mail: roberto.coellope@ug.edu.ec. *Corresponding author.

${ }^{2}$ Department of Animal Diagnostics, Phyto and Zoosanitary Regulation and Control Agency (AGROCALIDAD), Guayaquil, Ecuador.

${ }_{3}^{3}$ Faculty of Health Sciences and Social Service, State University of Milagro (UNEMI), Milagro, Ecuador.

ABSTRACT: Trypanosomosis in sheep is a hemoparasitic disease of worldwide interest due to its effects on the health of animals and the economic impact on producers, is caused by the protozoan Trypanosoma sp. In the present study, the occurrence of Trypanosoma sp. in sheep from the urban-rural area of the canton Salitre was determined, through an applied study with a qualitative descriptive prospective crosssectional approach, carried out between October 1, 2019, and February 19, 2020. Blood samples were extracted from the jugular vein and analyzed by the blood smear method using the Giemsa and Diff-Quick staining techniques. Previously, in a first study realized between 2018 and 2019, 2 cases (2\%) of Trypanosoma sp., 1 case of Babesia sp. (1\%), and 4 cases of Anaplasma marginale (4\%) were identified, but without the presence of symptoms of the disease. However, in this new research study, of 170 animals sampled from 5 herds and aged between 3 and 8 years, 34 (20\%) were positive for Trypanosoma sp., 6 for Babesia sp. (3.52\%) and 6 for A. marginale (3.52\%) with coinfection between them. In this research, deteriorated clinical aspects and low hematological values were also determined in positive animals; besides of the total of positive cases, 25 presented symptoms of hemoparasitic disease, 3 sheep had abortions and 8 died. The results of this study showed that Trypanosoma sp. could already become an endemic parasitosis in sheep in the country, representing a serious problem of animal health. Key words: Trypanosomosis, sheep, coinfection, clinical aspects, hematological values.

Infecção natural do Trypanosoma sp. em ovelhas domésticas do Equador

RESUMO: A tripanossomose em ovinos é uma doença hemoparasitária de interesse mundial devido a seus efeitos sobre a saúde dos animais e o impacto econômico sobre os produtores, Esta doença é causada pelo protozoário Trypanosoma sp. No presente estudo, foi determinada a ocorrência de Trypanosoma sp. em ovelhas da área urbano-rural do Cantão Salitre, através de um estudo aplicado com uma abordagem transversal descritiva qualitativa prospectiva, realizado entre dia primeiro de outubro de 2019, à 19 de fevereiro de 2020. Amostras de sangue foram extraídas da veia jugular e analisadas pelo método de esfregaço de sangue usando as técnicas de coloração Giemsa e Diff-Quick. Anteriormente, em um primeiro estudo realizado entre 2018 e 2019, dois casos (2\%) de Trypanosoma sp., foram identificados um caso de Babesia sp. (1\%), e quatro casos de Anaplasma marginale (4\%), mas sem a presença de sintomas da doença. Entretanto, neste novo estudo de pesquisa, de 170 animais amostrados de cinco rebanhos e com idades entre três e oito anos, 34 (20\%) foram positivos para Trypanosoma sp., seis para Babesia sp. (3,52\%) e seis para A. marginale (3,52\%) com coinfecção entre eles. Nesta pesquisa, aspectos clinicos deteriorados e baixos valores hematológicos também foram determinados em animais positivos; além do total de casos positivos, 25 apresentaram sintomas de doença hemoparasítica, três ovelhas tiveram abortos e oito morreram. Os resultados deste estudo mostram que o Trypanosoma sp. já poderia se tornar uma parasitose endêmica em ovinos no país, representando um grave problema de saúde animal.

Palavras-chave: Trypanossomose, ovelhas, coinfecção, aspectos clínicos, valores hematológicos.

\section{INTRODUCTION}

Trypanosomosis in sheep are an animal health problem and represent one of the main limitations in the development of the sheep industry in Africa, Asia, and Latin America (NG'AYO et al. 2005; PARRA-GIMENEZ \& REINA BELLO, 2019). The tangible economic losses caused by parasitic diseases are attributed mainly to reduced weight gain, lower milk production, diminished fertility, high mortality, and high costs of veterinary care (PARRAGIMENEZ \& REINA BELLO, 2019).

In Africa, animal trypanosomosis are widely distributed and are caused by Trypanosoma (T.) congolense, T. vivax, T. evansi, T. simeae, $T$. brucei, T. equiperdum, and T. theileri. In South America, the species causing animal trypanosomosis are Trypanosoma cruzi, T. equiperdum, T. evansi, and $T$. vivax. These trypanosomes, which parasitize livestock, sheep and a wide range of wildlife, are 
being maintained and transmitted in different ways (DÁVILA \& SILVA, 2000), which represents a potential risk for almost 300 million cattle, 1.8 million buffalo and 16 million horses (TOMASSI et al. 2018).

Only two species of trypanosomes with veterinary implications in South America have been identified due to their pathogenicity in sheep: T. vivax and T. evansi. However, Sanchez et al. confirmed the first molecular report of $T$. equiperdum in horses from Latin America (PARRAGIMENEZ \& REINA BELLO, 2019). In South America, T. vivax can infect cattle, horses, water buffalo, sheep, goats, deer, alpacas, llamas (DÁVILA \& SILVA, 2000), rodents and, is also reported in atypical human infections (GIORDANI, et al. 2016). T. evansi most notably affects horses and camels and can also affect donkeys, dogs, cats, cattle, goats, sheep and buffalo. Other wild mammals, such as capybaras (Hydrochoerus hydrochaeris), can act as reservoirs. The parasite has spread throughout the continent, where it is now endemic from Brazil to Costa Rica, including Colombia, Venezuela, Peru, Bolivia, Panama, Paraguay, and Ecuador (PARRAGIMENEZ \& REINA BELLO, 2019).

T. vivax measures between 18 and $26 \mu \mathrm{m}$ in length; has a rounded posterior end, central nucleus, modest undulating membrane, free flagellum at anterior end terminus, and a large kinetoplast; and is essentially monomorphic (GIORDANI, et al. 2016). While T. evansi is large in size, it measures between 15 and $35 \mu \mathrm{m}$ in length; has a thin posterior extremity, central nucleus, large undulating membrane, free flagellum, and a small and minimal kinetoplast; and is also essentially monomorphic (DESQUESNES, M., et al. 2013).

The clinical signs and symptoms caused by Trypanosoma sp. in South America include fever, emaciation, suppression of milk yields, anemia, limb edema, abortion, occasional death, nervous symptoms, lethargy, loss of appetite, and diarrhea leading to rapid and progressive weight loss. Animals that recover from the disease can become carriers, showing low and undetectable parasite levels in the blood (DÁVILA \& SILVA, 2000; PARRAGIMENEZ \& REINA BELLO, 2019). Current experimental and clinical evidence on animal trypanosomosis suggests that the main pathogenetic mechanisms of anemia include hemolysis, red blood cell (RBC) sequestration, hemodilution, platelet aggregation, lipid peroxidation, bleeding, and bone marrow dysfunction (BOADA, et al. 2016); furthermore, it is important to mention that diagnosis by direct parasitological means is effective when parasites are present in large quantities in the peripheral blood (TOMASSI et al. 2018).

In Ecuador, the native sheep is $90 \%$ adapted to extreme weather and management conditions; the production is in hands of marginal peasants, who use the sheep to obtain food and clothing, fertilize their fields and obtain certain profits (ANCO, 2019). There are approximately 739,475 sheep in the country (SILVA, 2018). At present, no outbreaks of trypanosomosis have appeared in sheep since the first cases appeared between October 1, 2018 and January 29, 2019; therefore, the present study aimed to determine the occurrence of Trypanosoma sp. and coinfection with other hemoparasites, as well as establishing the clinical aspects, percentage of abortions and mortality, physical condition, conjunctival status, and hematological values in positive sheep belonging to the canton Salitre in Ecuador.

\section{MATERIALS AND METHODS}

\section{Study area and time period}

This study was conducted on 5 farms in the rural sector of the canton Salitre, located in the northern part of the province of Guayas, on the Ecuadorian coast. Its geographical coordinates are $1^{\circ} 49^{\prime} 46^{\prime \prime}$ south latitude and $79^{\circ} 48^{\prime} 56^{\prime \prime}$ west longitude; the city has 73,000 inhabitants, of which 37000 live in urban areas and 40000 live in rural areas. Additionally, the canton Salitre has 5 rural parishes: Vieja Salitre, General Vernaza, Dos Esteros, La Victoria and Junquillal (Figure 1).

The city has an altitudinal range of 7 m.a.s.l. and a humid-tropical climate, with marked differences between winter (rainy) and summer (dry), with temperatures ranging from $20^{\circ} \mathrm{C}$ in the summer to $35{ }^{\circ} \mathrm{C}$ in the winter. Conversely, an applied, qualitative, descriptive, prospective cross-sectional study was carried out between December 1, 2019, and February 19, 2020, which is the winter season with rainy and hot weather.

\section{Census and Sampling}

Before obtaining samples, the research procedures were analyzed and approved by the Research Coordination of the Faculty of Veterinary Medicine of the University of Guayaquil, following the protocols of authors such as AL-KHALIFA et al. (2009); ADEJINMI et al. (2010DQB1, and DPB1 loci reveals contrasting levels of diversity at the allele and amino acid site levels. Statistics of allele frequency distributions, based on Watterson's 


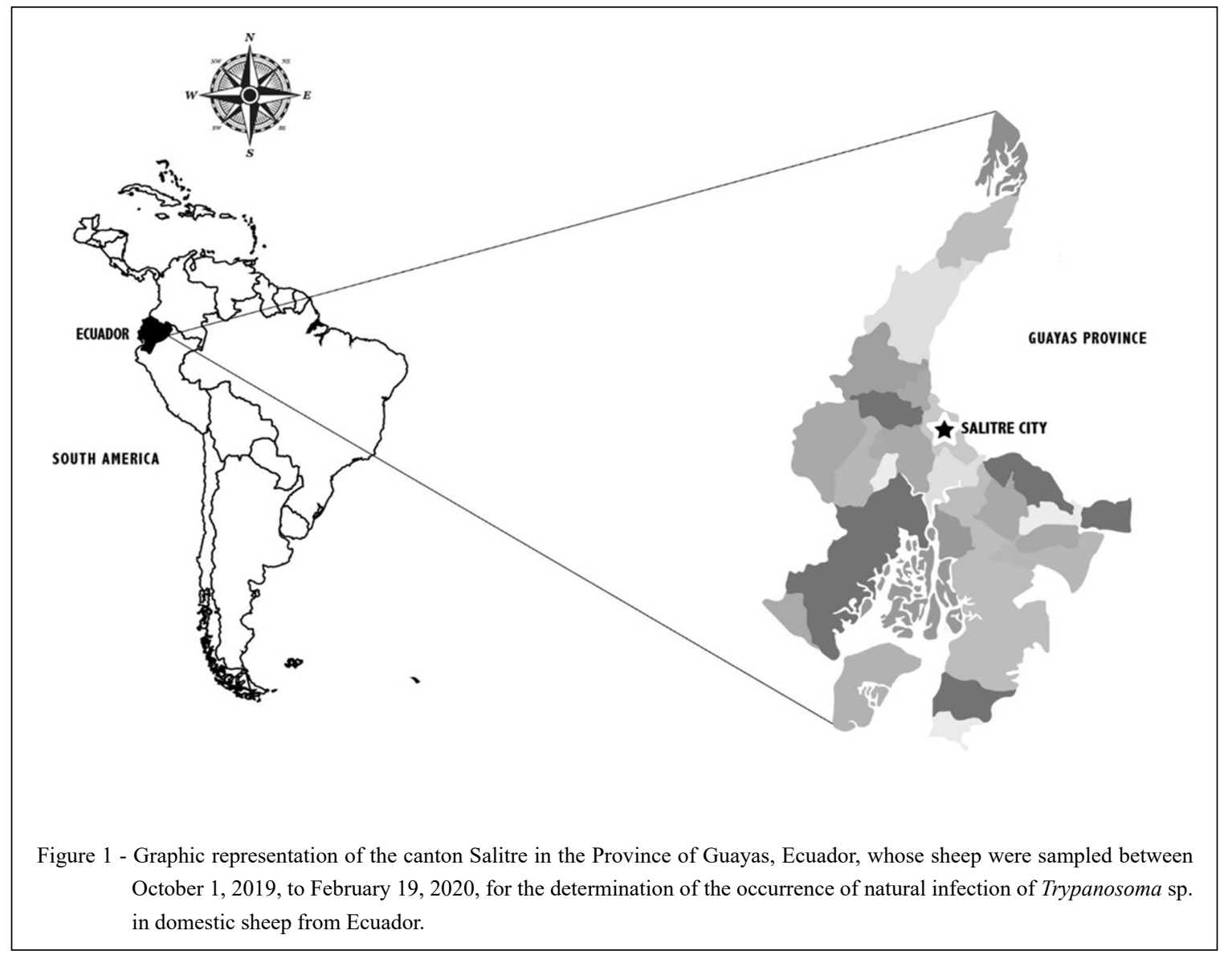

homozygosity statistic F, reveal distinct evolutionary patterns for these loci in ethnically diverse samples (26 populations for DQB1 and DRB1 and 14 for DPB1) and SEBELE et al., (2015); after approval, a census was conducted during the first week of December 2019 in the 5 rural areas studied (Vieja Salitre, General Vernaza, Dos Esteros, La Victoria and Junquillal), where there were a total of 450 animals (90 sheep per area). Afterwards, the inhabitants of the farms were informed about the importance of carrying out the investigation and the risk of the disease in infected animals; then, informed consent was requested from the domestic sheep owners (person who did not give consent was excluded from the study), and after acceptance, a simple random sampling was performed, in which blood samples were taken directly from the jugular vein of 170 sheep with ages between 3 and 8 years from 5 farms in the rural zone of the canton Salitre. The following sampling procedure was then performed: the animal was restrained, excess hair was shaved, complete antisepsis was performed on the sample extraction area, and pressure was exerted on the vacutainer tube containing EDTA (ethylenediaminetetraacetic acid) anticoagulant. Then, approximately $4 \mathrm{~mL}$ (NIST) of blood was extracted under vacuum and transported in a cooler, maintained at a temperature between 4 and $8{ }^{\circ} \mathrm{C}$ using cooling gel, to the Laboratory of Animal Diagnostics of the Phytosanitary and Zoosanitary Regulation and Control Agency (AGROCALIDAD) of Guayaquil, where the samples were analyzed.

Additionally, in the present study, the following data were recorded: symptoms, body condition, temperature, conjunctiva status (MUNOZ et al. 2019), abortions and death of animals. Regarding body condition, the following clinical parameters were analyzed: state $1=$ extremely low weight animal; state 2 = low weight animal; state 3 = animal in good condition; state $4=$ overweight animal; and stage $5=$ obese animal (MENDOZA et

Ciência Rural, v.52, n.2, 2022. 
al. 2011; MUNOZ et al. 2019); the body temperature of the sheep studied was classified using the following parameters: $>40{ }^{\circ} \mathrm{C}=$ fever-pyrexia (hyperthermia); $39-40{ }^{\circ} \mathrm{C}=$ normal; $37-39^{\circ} \mathrm{C}=$ moderate hypothermia; and $<37{ }^{\circ} \mathrm{C}=$ severe hypothermia (MENDOZA et al., 2011); conjunctiva status was determined using criteria published by MENDOZA et al. (2011): status 1 = optimal; status $2=$ normal, acceptable; status $3=$ intermediate; status $4=$ dangerous; and status $5=$ fatal. In relation to the occurrence of abortions and deaths of animals in this investigation, the presence or absence of cases was determined.

\section{Laboratory analysis}

Blood smears were performed with Giemsa and Diff-Quick staining separately, as described by AL-KHALIFA et al. (2009) and SEBELE et al. (2015). The samples were analyzed under a microscope $(100 \times$ objective) using oil immersion to identify Trypanosoma sp. and other haemoparasites. Additionally, hematological values for sheep were determined, such as hemoglobin (9.6-12.2 g/dL), packed cell volume (PVC) with limit intervals between 30 and $37 \%$ and the total erythrocyte count with limit intervals of 5.3 to 10.1 million per cubic millimeter of blood $\left(\times 10^{6} / \mathrm{uL}\right)$, using procedures and references described by RAHMAN et al. (2018).

\section{RESULTS}

During this study, 170 samples were analyzed, of which 114 were female and 56 were male; of the total samples processed, 34 (20\%) animals were positive for Trypanosoma sp., (Figure 2).

Of the 34 positive samples, 9 belonged to asymptomatic animals $(26.47 \%)$, and 25 were from symptomatic animals $(73.53 \%)$; of the latter, 3 had abortions (12\%), and 8 died (32\%), all with diagnoses of Trypanosoma sp. only.

During the study, the following were also observed: 6 animals were positive for Babesia sp. $(3.52 \%)$ and 6 animals were positive for Anaplasma marginale $(3.52 \%)$. Furthermore, the results indicated hemoparasitic coinfection between Trypanosoma sp. and Babesia sp. in 6 samples; also, coinfection between Trypanosoma sp. and Anaplasma marginale was determined in 6 samples $(3.52 \%)$.

The 25 animals that were positivesymptomatic during the study period presented symptoms of hemoparasitism, including fever (41-42 $\left.{ }^{\circ} \mathrm{C}\right)$, emaciation, suppression of milk yield, anemia, loss of appetite, weight loss, lethargy, weakness, pale mucous membranes, rough-haired coat, diarrhea and, in severe cases, hypothermia (35$36{ }^{\circ} \mathrm{C}$ ), rectal hemorrhage, abortions, neurological signs (incoordination, hypermetry, muscular tremors, blindness, and strabismus) and death. The physical condition of the symptomatic animals deteriorated, and of the 25 symptomatic animals with respect to body status, 10 were status 1 (extremely low weight animal) and 15 were status 2 (low weight animal). Likewise, presented conjunctiva state between state $4=$ dangerous and state $5=$ fatal and temperatures between 40 to $43{ }^{\circ} \mathrm{C}$ (MENDOZA et al., 2011). Conversely, the hematological values of symptomatic sheep, especially those that presented coinfection with other hemoparasites, showed a mean hemoglobin of $6.2 \mathrm{~g} / \mathrm{dL}$, a packed cell volume (PVC) between 20 and $25 \%$ and a total erythrocyte count (TEC) of 2 to 3.2 million per cubic millimeter of blood; asymptomatic and negative animals showed normal values (mean hemoglobin 10-12; PVC between 32 and $37 \%$ and total erythrocyte count between 6 to $10 \times 10^{6} / \mathrm{uL}$ of blood.

The origin of the infected animals was from the five farms studied, with a distance of $25 \mathrm{~km}$ between them. Additionally, it is important to point out that the presence of vectors was observed in all farms; in addition, two owners of sheep positive for Trypanosoma sp. stated that they bought three sheep from a farm in the town of Colimes (Guayas Province), which is the site where Trypanosoma sp. and other hemotropics were first determined in sheep of Ecuador (COELLO et al. 2020); finally, the inhabitants of the studied sector were educated regarding hemoparasitic disease prevention in their sheep through talks.

\section{DISCUSSION}

Among the morphological characteristics of Trypanosomas sp. observed were: monomorphic protozoa, between 15 and $30 \mu \mathrm{m}$ in length; rounded posterior end, central nucleus, modest wavy membrane, median free flagellum, and terminal and the median kinetoplast. These direct parasitological diagnoses were effective because parasites were present in large numbers in the peripheral blood and were associated with species of T. vivax and T. evansi, as described by DESQUESNES, M., et al. (2013).

Several probable or suggested methods of surra transmission exist: by biting insects including horseflies and stable flies (the major credited route), by vampire bats, by iatrogenic (e.g. as a result of a vaccination intervention), sexual, horizontal, or vertical transmission, or by per-oral contamination in the case of carnivores eating infected meat 


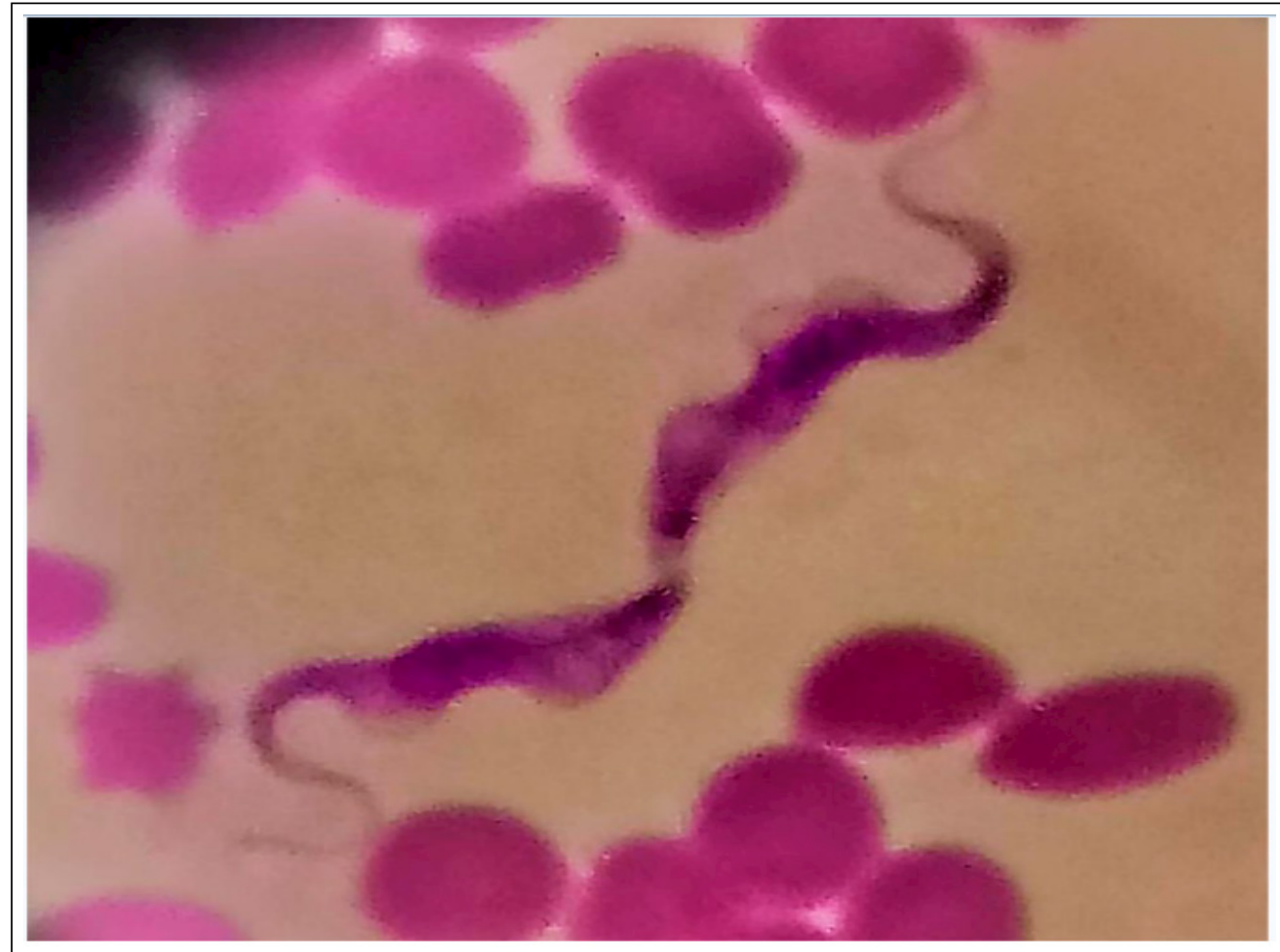

Figure 2 - Microscopic identification with Diff-Quick staining to 100X of Trypanosoma sp. in blood smears of sheep of the canton Salitre (Guayas) from Ecuador, analyzed between October 1, 2019, to February 19, 2020.

(DESQUESNES et al. 2013; GIORDANI et al. 2016). Trypanosoma spp. affect different species of domestic and wild animals, such as horse, mule, donkey, camel, cattle, buffaloes, sheep, goat, dog, pig, elephant, deer, fox, tiger and jackal (KUMAR et al. 2015).

In the present study, the occurrence of Trypanosoma sp. was identified in 34 animals (20\%), and in Paraguay, 1 case has been reported (TOMASSI et al., 2018); In addition, the percentage of determined cases $(20 \%)$ is higher than those reported in countries such as Ecuador (2\%) (COELLO et al. 2020), Iraq (3.3\%) (HASAN, 2012), Nigeria (3.03\%) (ADEMOLA \& ONYIQUE, 2013) and Spain (7.48.4\%) (DANIEL et al., 1994; RODRÍGUEZ, 2012). In contrast, the percentage of determined cases $(20 \%)$ is among the cases reported in Venezuela (9.75$62.3 \%$ ) (MORA \& CASTRO, 2015) and below the cases reported in Brazil (25.4-78.43\%) (BATISTA et al., 2009; GALIZA et al. 2011), Kenya (25.3\%) (NG'AYO et al., 2005), Colombia (34,8-46.2\%) (AVILA et al., 2013) and a new effectiveness review is needed. The authors reviewed the published literature to synthesize information on what is and what is not effective related to telemental health. Terms for the search included, but were not limited to, telepsychiatry, effectiveness, mental health, e-health, videoconferencing, telemedicine, cost, access, and international. Telemental health is effective for diagnosis and assessment across many populations (adult, child, geriatric, and ethnic and Nicaragua (4785\%) (MORA \& CASTRO, 2015). Likewise, natural infections with $T$. evansi in sheep have been reported in countries such as Egypt, Ethiopia, Sudan, India, Guyana and Spain; in these countries, an accumulated percentage of cases between 1 to $27 \%$ has been reported (AREGAWI et al. 2019). In addition, $T$. vivax prevalence in sheep in some countries of the world is between 1 and 62\% (MORA\& CASTRO, 2015; TOMASSI et al., 2018).

In this study, the presence of Trypanosoma sp. was identified in sheep from Ecuador, reporting a high occurrence $(20 \%)$, presumably due to the high parasitic or enzootic infection and an adequate transmission interaction between the parasites-hosts 
and the environment. Furthermore, in this study, 6 animals were positive for Babesia sp. (3.52\%), and 6 animals were positive for $A$. marginale $(3.52 \%)$. In contrast, COELLO et al. (2020), in the first study carried out in Ecuador between October 1, 2018, and January 29, 2019, determined a lower prevalence of $1 \%$ for Babesia sp. and $4 \%$ for $A$. marginal; Also, prevalences have been reported in Colombia $73.7 \%$ for Anaplasma sp. (AVILA et al., 2013), Egypt $1.53 \%$ for Babesia ovis (HUSSEIN et al, 2017), Iraq $62.6 \%$ for Anaplasma ovis and $1.5 \%$ for Babesia ovis (RENNEKER et al, 2013), Sudan 19, 82\% for Anaplasma sp. and 46.70\% for Babesia sp. (MOHAMMED et al, 2018), Turkey $41.1 \%$ for Anaplasma ovis and 5.4\% for Babesia sp. (BILGIN et al, 2017), and China $63.8 \%$ for Anaplasma ovis and between 5 to $18.6 \%$ for Babesia sp. (Li et al, 2020).

Regarding the hemoparasitic coinfection determined in this study, Trypanosoma sp. and Babesia sp. were reported in 6 cases (3.25\%) and Trypanosoma sp. and A. marginale were reported in 6 cases (3.25\%). Although there is little information about the coinfection between Trypanosoma sp. and other hemoparasites in sheep worldwide, ELHAIG et al. (2016) described a coinfection between Trypanosoma sp. and Babesia sp. in Egyptian sheep at $1.6 \%$, and TOMASSI et al. (2018) also described a case of coinfection in Paraguay. In addition, COELLO et al. (2020) reported a coinfection of Trypanosoma sp. and A. marginal in ewes from Ecuador of 1\%; and KASOZI et al. (2019) reported in Uganda a co-infection between the latter hemoparasites, of $3.65-5.76 \%$.

Infection and the occurrence of diseases transmitted by flies and ticks are determined by the coexistence and complex interactions between hosts, vectors, parasites, and are conditioned by the presence of biotic and abiotic factors that affect transmission. (ÁVILA et al. 2013; GIORDANI et al. 2016).

It is important to highlight that the 25 hemoparasite-positive and symptomatic animals, presented deteriorated physical condition (extremely low weight animal; and low weight animal) and conjunctival status between dangerous and fatal and, occurred during the rainy season, in a coastal region with a humid tropical climate; these cases are similar to those reported by BATISTA et al. (2009) and GALIZA et al. (2011) in Brazil; MORA \& CASTRO et al. (2015) in Nicaragua and TOMASSI et al. (2018) in Paraguay. Conversely, the 9 positive asymptomatic animals and the other negative animals, presented good body condition, intermediate conjunctiva state, and a temperature of $39^{\circ} \mathrm{C}$, as described by ADEMOLA
\& ONYIQUE (2013), SEBELE et al. (2015) and COELLO et al. (2020).

Regarding the symptoms present in positive sheep, such as fever, emaciation, suppression of milk yield, anemia, loss of appetite, weight loss, lethargy, weakness, pale mucous membranes, rough haired coat, diarrhea and, in severe cases, hypothermia, hemorrhage, abortions, neurological signs and death; are very similar to the outbreaks described by BATISTA et al. (2009) and GALIZA et al (2011) in Brazil.

In relation to the evaluation of hematological values of hemoglobin, packed cell volume (PVC) and the total erythrocyte count, lower values were determined, as described by BATISTA et al (2009), GALIZA et al (2011), MORA \& CASTRO (2015) and PARRA-GIMENEZ \& REINA BELLO (2019).

This study reported a $1.76 \%$ abortion rate and a mortality percentage of $4.70 \%$; while, in Brazil, BATISTA et al. (2009) described an abortion rate of around $2 \%$ and a mortality rate of $10.1 \%$; GALIZA et al. (2011) reported more than $70 \%$ of abortions and deaths; ALVES et al. (2008) describe a mortality rate between 12 and 70\%, MORA \& CASTRO (2015) reported 100\% morbidity, and GIORDANI et al. (2016) described high rates of morbidity, mortality, and infertility in the absence of treatment.

Trypanosomosis infections are very common in Africa and the Americas in sheep, and these infections can be transmitted to other animals, such as goats, cows, buffalo, horses, pigs, donkeys, and domestic cats and dogs, because they share a common habitat among them (GALIZA, et al. 2011; PARRA-GIMENEZ \& REYNA-BELLO, 2019). However, sheep are more frequently infected with Trypanosoma sp. than goats and pigs under natural conditions. In Africa, it has been reported that sheep, goats, and pigs, which are raised together with cattle, can harbor infectious trypanosomes for humans. (Trypanosoma brucei rhodesiense y gambiense) (NG'AYO, et al. 2005); in Las Américas, infectious trypanosomes for human beings (T. cruzi) have been reported in sheep, goats, pigs, and cattle that keep a relationship with reservoirs (domestic and wild) and the vector (ACHA \& SZYFRES, 2003; GÜRTLER \& CARDINAL, 2015); in Europe, recent imported cases of T. evansi have been documented, and vigilance remains necessary after outbreaks in the Canary Islands, mainland Spain, France, and Germany (GIORDANI, et al. 2016).

The outbreak of T. vivax in 1995 in a region that includes the Brazilian Pantanal and the Bolivian lowlands, where livestock is the most 
important economic activity (11 million head of cattle are reared in the region), caused losses to the industry totaling an estimated of $\$ 160$ million. Additionally, in the Brazilian Pantanal regions, T. evansi affects more than 6000 horses a year, causing economic losses of US \$2-4 million (GIORDANI, et al. 2016).

This study indicated that hemotropic parasites are present in the blood of sheep in the canton Salitre, which is influenced by climatic characteristics that favor the presence of vectors for the transmission of this parasitosis, but there is a potential risk of cases of the disease occurring in surrounding areas due to the presumption of parasitic circulation in infected vectors.

With these events exposed, we suggested that the blood samples from the animals be subjected to confirmatory tests (PCR) to determine the species of Trypanosoma, as described by N'DJETCHI et al. (2017) in Africa. These data, in addition to enriching the research, are valuable information for local health authorities and the OIE.

\section{CONCLUSION}

The authors described the presence of cases of trypanosomosis in domestic sheep from 5 farms in the rural area of the city of Salitre in Ecuador, determining the occurrence of Trypanosoma $\mathrm{sp}$. (20\%), A. marginale (3.52\%) and Babesia sp. (3.52\%), using the Giemsa and Diff-Quick stained blood smear method; besides, the coinfection between Trypanosoma sp. and $A$. marginale (3.52\%), as well as Trypanosoma sp. and Babesia sp (3.52\%) was determined. This implies an acute infection of hemoparasites with the presence of low hematological values and signs and symptoms of disease in positive sheep at the study site. Likewise, the positive animals investigated had the presence of dangerous and fatal body conditions, with the presentation of abortions and deaths.

This research is important because it shows that the parasites detected are present in the country and can cause epizootics in other sectors; likewise, this information is relevant for epidemiological surveillance and animal health systems; also, it is important to improve the dissemination and promotion of educational programs on these parasites and to establish effective control measures to prevent the infection spread in herds.

\section{ACKNOWLEDGMENTS}

The authors thank MSc. Allan Sotomayor Marin for allowing us to work in the Animal Diagnostic Laboratory of the Agency for the Regulation and Control of Phytosanitary and Zoosanitary (Agrocalidad) of Guayaquil - Ecuador, to the owners of sheep who gave their consent to investigate in their animals, and to the Coordination of Research from the Faculty of Veterinary Medicine and Zootechnics of the University of Guayaquil for having reviewed the research methodology.

\section{DECLARATION OF CONFLICT OF INTERESTS}

The authors covered the full funding of the research; therefore, there is no conflict of interest with any financial organization regarding the material discussed in the manuscript.

\section{AUTHORS' CONTRIBUTIONS}

The authors contributed equally to the manuscript.

\section{REFERENCES}

ACHA, P. \& SZYFRES, B. Zoonoses and Communicable Diseases Common to Man and Animals: Parasitoses. In: Pan American Health Organization (PHO), World Health Organization (WHO). 3.ed. Washington (EEUU), 2003. p. 1-395. Online. Available from: $<$ https://www.paho.org/hq/dmdocuments/2010/ZoonosesVol-3. pdf $>$. Accessed: Apr. 07, 2021.

ADEJINMI, J. et al. Studies on the blood parasites of sheep in Ibadan, Nigeria. African Journal of Biomedical Research, v.7, n.1, p.1975-1977, 2010. Available from: <https://doi.org/10.4314/ajbr. v7i1.54066>. Accessed: Mar. 24, 2020. doi: 10.4314/ajbr.v7i1.54066.

ADEMOLA, I. O. \& ONYICHE, T. E. Haemoparasites and Haematological Parameters of Slaughtered Ruminants and Pigs at Bodija Abattoir, Ibadan, Nigeria. Afr. J. Biomed. Res, v.16, n.2, p.101-105, 2013. Available from: <https://www.researchgate.net/ publication/279998351>. Accessed: Aug. 24, 2020.

AL-KHALIFA, M. S. et al. Blood parasites of livestock in certain Regions in Saudi Arabia. Saudi Journal of Biological Sciences, v.16, n.2, p.63-67, 2009. Available from: $<$ https://doi. org/10.1016/j.sjbs.2009.10.002>. Accessed: Mar. 14, 2020. doi: 10.1016/j.sjbs.2009.10.002.

ALVES, A. L. et al. Trypanosoma (Duttonella) vivax: its biology, epidemiology, pathogenesis, and introduction in the New World A review. Mem. Inst. Oswaldo Cruz, v.103, n.1, p. 1-13, 2008. Available from: $<$ https://www.scielo.br/scielo.php?script=sci_artt ext\&pid=S0074-02762008000100001>. Accessed: Aug. 25, 2020. doi: 10.1590/S0074-02762008000100001.

ANCO (Nacional Association of Sheep of Ecuador). The Sheep Industry in Ecuador, 2019. Available from: <http://www. geocities.ws/ancoec/industry.html>. Accessed: Mar. 14, 2020.

AREGAWI, W. G., et al. (2019). Systematic review and metaanalysis on the global distribution, host range, and prevalence of Trypanosoma evansi. Parasites \& Vectors, v12, n.67, 2019. Available from: <https://doi.org/10.1186/s13071-019-3311-4>. Accessed: Mar. 05, 2020. doi: 10.1186/s13071-019-3311-4.

AVILA PULGARIN, L. S., et al. Hemoparasite infection in goats and sheep at five municipalities in north and northeastern Antioquia 
(Colombia). Rev. CES Veterinary Medicine and Zootechnics, v.8, n.1, p.14-24, 2013. Available from: $<$ https:/dialnet.unirioja. es/servlet/articulo?codigo $=4424392>$. Accessed: Mar. 05, 2020. doi: $10.21615 / 2830$.

BATISTA, J. S., et al. Infection by Trypanosoma vivax in goats and sheep in the Brazilian semiarid region: From acute disease outbreak to chronic cryptic infection. Veterinary Parasitology, v.165, n.2, p.131-35, 2009. Available from: $<$ https://doi.org/10.1016/j. vetpar.2009.07.005>. Accessed: Aug. 25, 2020. doi: 10.1016/j. vetpar.2009.07.005.

BILGIN, H. et al. Prevalence of tick-borne haemoparasites in small ruminants in Turkey and diagnostic sensitivity of single-PCR and RLB. Parasites \& Vectors, v.10, n.211, p.1-13, 2017. Available from: <https://pubmed.ncbi.nlm.nih.gov/28449722/>. Accessed: Jan. 29, 2021. doi: 10.1186/s13071-017-2151-3

BOADA, A. A. et al. Trypanosoma vivax Adhesion to Red Blood Cells in Experimentally Infected Sheep. Patholog Res Int, p.1-9, 2016: Available from: <https://www.ncbi.nlm.nih. gov/pmc/articles/PMC4884851/>. Accessed: Apr. 05, 2020. doi: $10.1155 / 2016 / 4503214$

COELLO, R. D. et al. First report of sheep naturally infected with Trypanosoma sp. in Ecuador. Ciência Rural. v.51, n.1, p.295-97, 2020. Available from: <https://www.scielo.br/scielo. php? pid $=$ S0103-84782021000100501\&script $=$ sci arttext $>$. Accessed: Dec. 08, 2020. doi: 10.1590/0103-8478cr20200223.

DANIEL, A. D. et al. Prevalence of trypanosomosis in sheep and goats in a region of northern Nigeria. Revue d'élevage et de Médecine Vétérinaire Des Pays Tropicaux, v.47, n.3, p.295-97, 1994. Available from: <https://doi.org/10.19182/remvt.9091>. Accessed: Jan. 08, 2020. doi: 10.19182/remvt.9091.

DÁVILA, A. \& SILVA, R. A. Animal trypanosomosis in South America. Current status, partnership, and information technology. Ann N Y Acad Sci, v.916, n.1, p.199-212. 2000. Available from: $<$ https://pubmed.ncbi.nlm.nih.gov/11193622/>. Accessed: Aug. 20, 2020. doi: 10.1111/j.1749-6632.2000.tb05291.x.

DESQUESNES, M. et al. Trypanosoma evansi and surra: A review and perspectives on origin, history, distribution, taxonomy, morphology, hosts, and pathogenic effects. BioMed Research International, p.1-22, 2013. Available from: <https:// doi.org/10.1155/2013/194176>. Accessed: Jul. 15, 2020. doi: $10.1155 / 2013 / 194176$.

ELHAIG, M. M. et al. Molecular Confirmation of Trypanosoma evansi and Babesia bigemina in Cattle from Lower Egypt. Pakistan Veterinary Journal, p.1-6, 2016. Available from: <www.pvj.com pk>. Accessed: Aug. 26, 2020. doi: 315685513.

GALIZA, G. J. et al. High mortality and lesions of the central nervous system in trypanosomosis by Trypanosoma vivax in Brazilian hair sheep. Veterinary Parasitology, v.182, n.4, p.359-363, 2011. Available from: <https://pubmed.ncbi.nlm. nih.gov/21664764/>. Accessed: Aug. 28, 2020. doi: 10.1016/j. vetpar.2011.05.016

GIORDANI, F. et al. The animal trypanosomosis and their chemotherapy: a review. Parasitology, v.143, n.14, p.1862-1889, 2016. Available from: <https://www.ncbi.nlm.nih.gov/pmc/ articles/PMC5142301/pdf/S0031182016001268a.pdf $>$. Accessed: Aug. 21, 2020. doi: 10.1017/S0031182016001268.
GÜRTLER, R. \& CARDINAL, M. Reservoir host competence and the role of domestic and commensal hosts in the transmission of Trypanosoma cruzi. Acta Tropica, v.151, n.1, p.1-73, 2015. Available from: <https://pubmed.ncbi.nlm.nih.gov/26051910/>. Accessed: Aug. 21, 2020. doi: 10.1016/j.actatropica.2015.05.029.

HASAN, M. H. Diagnosis of some blood parasites in cattle and sheep in Mosul, Iraq. Iraqi Journal of Veterinary Sciences, v.26, n.57, p.57-61, 2012. Available from: <https://pdfs. semanticscholar.org/4341/4c675de70d191cfaa4f3a09d07083c889 edd.pdf>. Accessed: Jun. 05, 2020. doi: 10.33899/ijvs.2009.5692.

HUSSEIN, N. M. et al. Distribution pattern of babesia and theileria species in sheep in Qena Province, Upper Egypt. Archives of Parasitology, v.1, n1, p.1-4, 2017. Available from: <https://www. omicsonline.org/open-access/distribution-pattern-of-babesiaand-theileria-species-in-sheep-in-qena-provinceupper-egypt. php?aid=89927>. Accessed: Jan. 29, 2020.

KASOZI, K. et al. Prevalence of hemoprotozoan parasites in small ruminants along a human-livestock-wildlife interface in western Uganda. Vet Parasitol Reg Stud Reports, v.17, n.1, p.1-11, 2019. Available from: <https://pubmed.ncbi.nlm.nih.gov/31303220/>. Accessed: Dec. 25, 2020. doi: 10.1016/j.vprsr.2019.100309.

KUMAR, A. et al. Insight into trypanosomiasis in animals: Various approaches for its diagnosis, treatment and control: A review, Asian Journal of Animal Sciences, v.9, n.5, p.172-186, 2015. Available from: <http://docsdrive.com/pdfs/ansinet/ajas/2015/172-186.pdf >. Accessed: Aug. 27, 2020. doi: 10.3923/ajas.2015.172.186.

LI, Y. et al. Molecular detection and identification of Babesia spp., Theileria spp., and Anaplasma spp. in sheep from border regions, Northwestern China. Frontiers in Veterinary Science, v.7, n.630, p.1-6, 2020. Available from: <https://www. frontiersin.org/articles/10.3389/fvets.2020.00630/full>. Accessed: Jan. 29, 2021. doi: 10.3389/fvets.2020.00630.

MENDOZA, A. et al. Diagnóstico clínico del ovino. 1 ed. Tabasco, México: Universidad Juárez Autónoma de Tabasco, 2011. 86p. Available from: $<$ http://www.archivos.ujat.mx/2011/difusion/ libros/9.pdf $>$. Accessed: Jun. 15, 2020.

MOHAMMED S. et al. Incidence and prevalence of tickborne haemoparasites infecting sheep and goats in Sennar state, Sudan. International Journal of Biology Research, v.3, n.2, p.173-177, 2018. Available from: <https://www.researchgate. net/publication/327281786 Incidence and prevalence of tickborne_haemoparasites_infecting_sheep_and_goats_in_Sennar_ state Sudan>. Accessed: Jan. 29, 2021.

MORA, B. \& CASTRO, K. Infección por Trypanosoma sp. en ovinos sintomáticos en el Municipio de León, Nicaragua. Revista Científica de la UNAN-León, v.6, n.1, p.1-10, 2015. Available from: $\quad<$ http://revista.unanleon.edu.ni/index.php/universitas/ article/view/98/pdf 11>. Accessed: Jan. 05, 2020. doi: 10.22004/ ag.econ. 232902

MUNOZ, C., et al. Evaluating the welfare of extensively managed sheep. PLoS One. v.14, n.6, 2019. Available from: < https:// pubmed.ncbi.nlm.nih.gov/31216326/>. Accessed: Dic. 25, 2020. doi: 10.1371 journal.pone.0218603.

N'DJETCHI, M. K. et al. The study of Trypanosome species circulating in domestic animals in two human African trypanosomosis foci of Côte d'Ivoire identifies pigs and cattle as

Ciência Rural, v.52, n.2, 2022. 
potential reservoirs of Trypanosoma brucei gambiense. PloS Negl Trop Dis. v11, n.10, p. 1-16, 2017. Available from: $<$ https://www. ncbi.nlm.nih.gov/pmc/articles/PMC5662240/pdf/pntd.0005993. pdf $>$. Accessed: Jan. 05, 2020. doi: 10.1371/journal.pntd.0005993.

NG'AYO, M. O. et al. Detection of trypanosomes in small ruminants and pigs in western Kenya: Important reservoirs in the epidemiology of sleeping sickness?. Kinetoplastid Biology and Disease, v.4, n.5, p.1-7, 2005. Available from: <https:// doi.org/10.1186/1475-9292-4-5>. Accessed: Jun. 05, 2020. doi: $10.1186 / 1475-9292-4-5$.

PARRA-GIMENEZ, N. \& REYNA-BELLO, A. Parasitological, hematological, and immunological response of experimentally infected sheep with Venezuelan isolates of Trypanosoma evansi, Trypanosoma equiperdum, and Trypanosoma vivax. Journal of Parasitology Research, p.1-9, 2019. Available from: <https:// doi.org/10.1155/2019/8528430>. Accessed: Jan. 05, 2020. doi: $10.1155 / 2019 / 8528430$.

RAHMAN, K. et al. Determination of hematological and serum biochemical reference values for indigenous sheep (Ovies aries) in Dhaka and Chittagong Districts of Bangladesh. Vet World, v.11, n8, p.1089-1093, 2018. Available from: <https://www.ncbi.nlm. nih.gov/pmc/articles/PMC6141301/>. Accessed: Aug. 27, 2020. doi: 10.14202/vetworld.2018.1089-1093.

RENNEKER S. et al. Coinfection of Sheep with Anaplasma, Theileria and Babesia species in the Kurdistan Region, Iraq. Transboundary and Emerging Diseases, v.60, n2, p.113-118, 2013. Available from: <https://onlinelibrary.wiley. com/doi/epdf/10.1111/tbed.12148>. Accessed: Jan. 29, 2021. doi: $10.1111 /$ tbed. 12148

RODRÍGUEZ, N. F. Epidemiología clínica y molecular de la tripanosomosis animal por Trypanosoma evansi en Canarias. 2012. 270f. Thesis $\mathrm{PhD}$ in Clinic and Research Therapy. Department of Animal Pathology, Production Animal, Food Bromatology and Technology, Universidad de las Palmas de Gran Canaria. Available from: < https:/accedacris.ulpgc.es/ bitstream/10553/7744/4/0666425_00000_0000.pdf $>$. Accessed: Jul. 25, 2020 .

SEBELE, T., et al. A study of the prevalence of hemoparasites of ruminants in and around Debre-Zeit, Central Ethiopia. African Journal of Parasitology Research, v.2, n.3, p.66-71, 2015. Available from: <http://internationalscholarsjournals.org/ download.php?id=252848229449121554.pdf\&type=application/ pdf\&op=1>. Accessed: Jan. 05, 2020.

SILVA, A. Comportamiento productivo de ovinos alimentados con dietas a base de fruta de pan (Artocarpus altilis). 2018. 56f. Thesis of degree Faculty of Agricultural Sciences, Technical University of Ambato. Available from: <http://repositorio. uta.edu.ec/bitstream/123456789/25097/1/tesis\%20027\%20 Ingenier\%C3\%ADa\%20Agropecuaria $\% 20-\% 20$ Silva>.

TOMASSI, M., et al. Clinical case report: Trypanosomiasis in Sheep. Compendio de Ciencias Veterinarias. v.8, n.1, p.39-42, 2018. Available from: <https://doi.org/10.18004/compend.cienc. vet.2018.08.01.39-42>. Accessed: Jan. 05, 2020. doi: 10.18004/ compend.cienc.vet.2018.08.01.39-42. 